\title{
CASP8AP2 wt Allele
}

National Cancer Institute

\section{Source}

National Cancer Institute. CASP8AP2 wt Allele. NCI Thesaurus. Code C126618.

Human CASP8AP2 wild-type allele is located in the vicinity of $6 q 15$ and is approximately $45 \mathrm{~kb}$ in length. This allele, which encodes CASP8-associated protein 2, plays a role in the regulation of apoptosis. 